\title{
2-Hydroxy-4-Methoxybenzophenone Oxime as an Analytical Reagent for Copper(II)
}

\author{
MISS KRISHNA PUROHIT and K. K. DESAI* \\ Department of Chemistry, \\ Veer Narmad South Gujarat University, \\ Surat - 395007, Gujarat, INDIA
}

Received 26 February 2005; Accepted 25 March 2005

\begin{abstract}
HMBO) was developed as a new analytical reagent for the gravimetric determination of $\mathrm{Cu}(\mathrm{II})$. In $\mathrm{pH}$ 2.5-9.0 the reagent gives brown coloured precipitate with $\mathrm{Cu}(\mathrm{II})$. Spectrophotometric methods revealed that the stoichiometry of the complex is 1:2 (metal : ligand). Beer's law is obeyed up to $31.75 \mathrm{ppm}$ of $\mathrm{Cu}(\mathrm{II})$. Molar absorptivity and Sandell's sensitivity at 400 $\mathrm{nm}$ were found to be $7.0 \times 10^{2} \mathrm{Lmol}^{-1} \mathrm{~cm}^{-1}$ and $0.090 \mu \mathrm{g} / \mathrm{cm}^{2}$ respectively. The stability constant of $\mathrm{Cu}(\mathrm{II})-\mathrm{HMBO}$ complex is found to be $6.13 \times 10^{9}$. Gibb's free energy change for complex formation reaction was found to be $-13.93 \mathrm{Kcal} / \mathrm{mol}$. The reagent can be used for the analysis of brass.
\end{abstract}

Key words: Oxime, Analytical reagent, 2-hydroxy-4-methoxybenzophenoneoxime, HMBO

\section{Introduction}

In the current scenario of analytical chemistry, many reagents are widely available for gravimetric and spectrophotometric determination of metal ions. They include o-hydroxy ketoxime ${ }^{1-3}$, phenyl hydrazones, thiosemicarbozones ${ }^{4}$, chalcone oximes ${ }^{5}$ etc. In this work, we report the use of 2-hydroxy4-methoxybenzophenoneoxime (HMBO) as a gravimetric reagent for $\mathrm{Cu}(\mathrm{II})$. Spectrophotometric methods have been used to confirm the stoichiometry of the complex and to determine the stability constant of the complex. The reagent is used to determine copper in brass.

\section{Experimental}

Spectrophotometric measurements were made on a shimadzu UV 160-A recording spectrophotometer. All the $\mathrm{pH}$ measurement were done on Elico $\mathrm{pH}$ meter (LI-10T) and buffer solution of required $\mathrm{pH}$ were obtained using sodium acetate-acetic acid \& hydrochloric acid-sodium acetate buffers of suitable concentration. 
Synthesis of 2-hydroxy-4-methoxybenzophenone oxime (HMBO)

2-hydroxy-4-methoxybenzophenone manufactured by sigma was converted to oxime by sodium acetate method. It was crystallized from ethanol. Colourless needles (m.p. $\left.62 \pm 1{ }^{\circ} \mathrm{C}\right)(\mathrm{N}$ found $=5.76$ $\%$, calculated $=5.82$ ). The oxime is soluble in solvents like ethanol, acetone, carbontetrachloride etc.

Stock solution

Stock solution of $\mathrm{Cu}(\mathrm{II})(0.05 \mathrm{M})$ was prepared by dissolving $\mathrm{CuSO}_{4} \cdot 5 \mathrm{H}_{2} \mathrm{O}$ in distilled water and was used after standardization with EDTA. Stock solution of HMBO $(0.05 \mathrm{M})$ was prepared by dissolving oxime in $70 \%$ aqueous ethanol.

\section{Gravimetric procedure}

A $10.0 \mathrm{ml}$ aliquot of $\mathrm{Cu}(\mathrm{II})$ was diluted to $100 \mathrm{ml}$ with distill water, warmed and the $\mathrm{pH}$ of the solution was adjusted in the range of $2.5-9.0$ with suitable buffer. Then $0.05 \mathrm{M}$ solution of HMBO in ethanol was added till precipitation was complete (about $22.0 \mathrm{ml}$ added). The brown precipitate was digested on a water-bath at $60{ }^{\circ} \mathrm{C}$ for $1 \mathrm{hr}$ and filtered through a previously weighed sintered glass crucible $\mathrm{G}_{4}$. The precipitate was washed with hot water and finally with $70 \%$ aqueous ethanol to remove any reagent which might have precipitated on dilution. The precipitates were dried on at $110{ }^{\circ} \mathrm{C}$ and weighed.

\section{Gravimetric determination of $\mathrm{Cu}$}

To establish the applicability of the reagent for gravimetric estimation of $\mathrm{Cu}(\mathrm{II})$, the metal ion was determinate in the $\mathrm{pH}$ range $2.5-9.0$. The maximum error being $\pm 1 \%$. Estimation were done at $\mathrm{pH} 5$ using different aliquots of $\mathrm{Cu}$ (II). In all cases the error in $\mathrm{Cu}$ (II) content did not exceed $\pm 0.06 \%$ (Table - 1).

Table -1. Result of gravimetric estimation copper (II) at $\mathrm{pH} 5$; $\mathrm{Cu}(\mathrm{II}) \mathrm{HMBO}$

\begin{tabular}{ccccc}
\hline $\begin{array}{c}\text { Copper taken } \\
(\mathrm{mg})\end{array}$ & $\begin{array}{c}\text { Complex obtained } \\
(\mathrm{mg})\end{array}$ & $\begin{array}{c}\text { Copper found } \\
(\mathrm{mg})\end{array}$ & $\begin{array}{c}\text { Error } \\
(\mathrm{mg})\end{array}$ & $\begin{array}{c}\text { Percentage } \\
\%\end{array}$ \\
\hline 15.89 & 0.1370 & 15.90 & +0.01 & +0.06 \\
31.77 & 0.2737 & 31.76 & -0.01 & -0.03 \\
47.66 & 0.4110 & 47.68 & +0.02 & +0.04 \\
63.56 & 0.5480 & 63.57 & +0.01 & +0.01 \\
\hline
\end{tabular}

Effect of diverse ions

In gravimetric determination of copper $(31.77 \mathrm{mg})$ at $\mathrm{pH} 5$, it was found that $\mathrm{Ba}^{+2}, \mathrm{Ca}^{+2}, \mathrm{Sr}^{+2}, \mathrm{Al}^{+3}$, $\mathrm{Zn}^{+2}$ and common anions $\mathrm{Cl}^{-}, \mathrm{Br}^{-}, \mathrm{No}_{2}^{-}, \mathrm{So}_{4}^{-}$did not interfere. At this $\mathrm{pH} \mathrm{Pd}^{+2}, \mathrm{Co}^{+2} \& \mathrm{Fe}^{+3}$ interfere seriously.

Spectrophotometric studies

For taking the absorbance spectra $5 \mathrm{mg}$ chelate was dissolved in $25 \mathrm{ml}$ chloroform and the absorbance was measured in the range of $350-800 \mathrm{~nm}$. It was observed that absorbance of the solution increased continuously towards the shorter wavelength. The absorbance spectrum showed a shoulder at $400 \mathrm{~nm}$ and hence all measurements were carried out at $400 \mathrm{~nm}$.

$\mathrm{The} \mathrm{Cu}(\mathrm{II})-\mathrm{HMBO}$ complex is insoluble in methanol and ethanol. It is soluble in solvents like chloroform, MIBK, 1:4 dioxane etc. Hence the complex was extracted in chloroform. For spectrophotometric studies varying amount $\mathrm{Cu}$ (II) solution was taken and $\mathrm{pH}$ was adjusted to 5 with $\left(\mathrm{CH}_{3} \mathrm{COOH}+\mathrm{CH}_{3} \mathrm{COONa}\right)$ buffer and $\mathrm{HMBO}$ solution was extracted with three $5 \mathrm{ml}$ portion of $\mathrm{CHCl}_{3}$ and the volume of $\mathrm{CHCl}_{3}$ extract was made up to $25 \mathrm{ml}$ the absorbance of $\mathrm{CHCl}_{3}$ extract was measured against solvent blank.

Validity of Beer's law

The $\mathrm{Cu}(\mathrm{II})$-HMBO complex in chloroform obeys law up to $31.75 \mathrm{ppm}$ of $\mathrm{Cu}(\mathrm{II})$. Beyond this concentration the absorbance plot showed deviation from linearity. The molar absorptivity of the complex obtained from absorbance data is found to be $7.0 \times 10^{2} \mathrm{Lmol}^{-1} \mathrm{~cm}^{-1}$ at $400 \mathrm{~nm}$. The Sandell was found $0.090 \mu \mathrm{g} / \mathrm{cm}^{2}$ of $\mathrm{Cu}$ (II) at $400 \mathrm{~nm}$. 


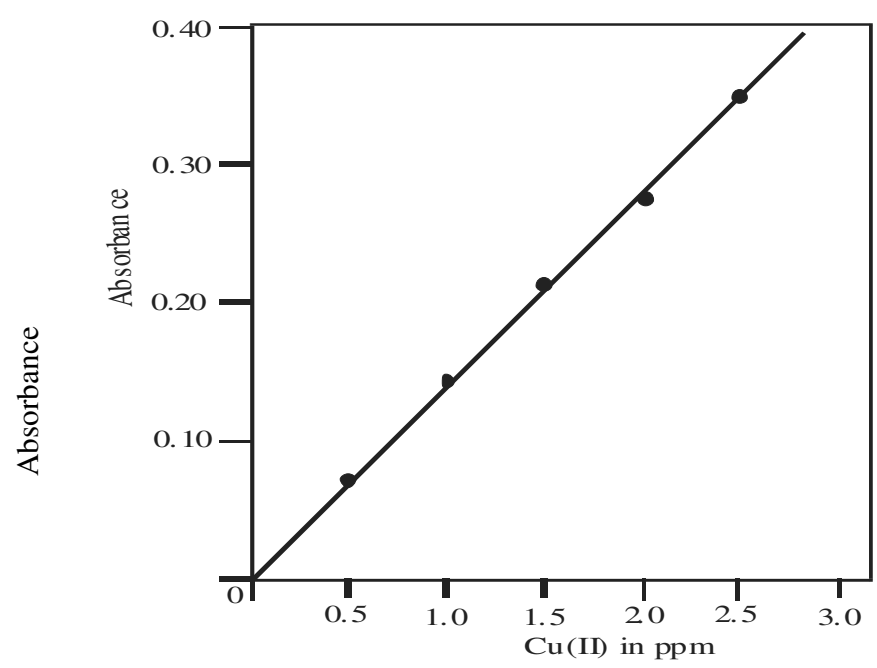

Graph - 1

Stoichiometry and stability constant of complex

The stoichiometry of $\mathrm{Cu}(\mathrm{II})$-HMBO complex was determined by (1) Job's method ${ }^{6}$ of continuous variation and (2) Yoe and Jones mole-ratio method ${ }^{7}$. Both the methods gave the metal : ligand ratio of $1: 2$. The stability constants were calculated using the formula:

$$
\mathrm{Ks}=1-\alpha / 4 \alpha^{3} \mathrm{c}^{2}
$$

Where, $\alpha=$ Em-Es / Em, (Em is the maximum absorbance found from graph and Es is the absorbance at stoichiometric molar ratio of the reagent in the complex), and it was found to be $6.13 \times 10^{9}$ from Ks value. Gibb's free energy change for complex formation reaction was calculated and its value was found $-13.43 \mathrm{Kcal} / \mathrm{mol}$ at $27{ }^{\circ} \mathrm{C}$. The graphs were shown below:

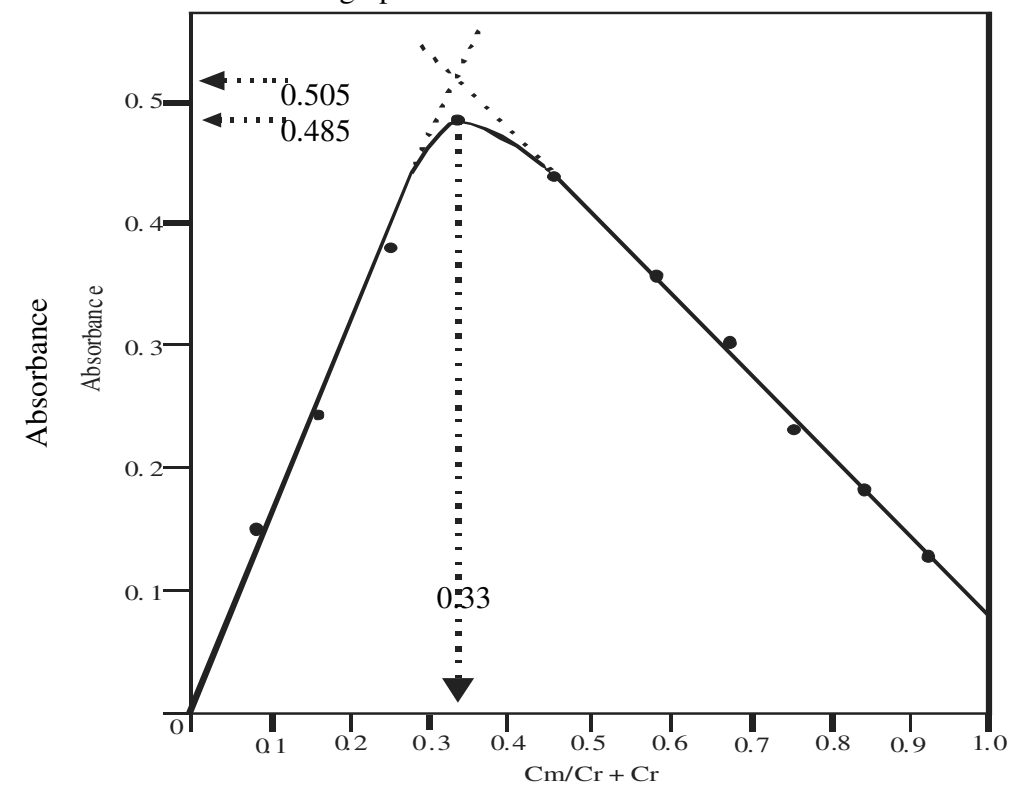

Graph - 2. Job's method for $\mathrm{Cu}(\mathrm{II})$-HMBO complex

Plots of Job's method of continuous variation for determination of M:L ratio $0.005 \mathrm{M} \mathrm{Cu}(\mathrm{II}), 0.005 \mathrm{M} \mathrm{HMBO} ; p H=5.0 ; \lambda=400 \mathrm{~nm}$ 


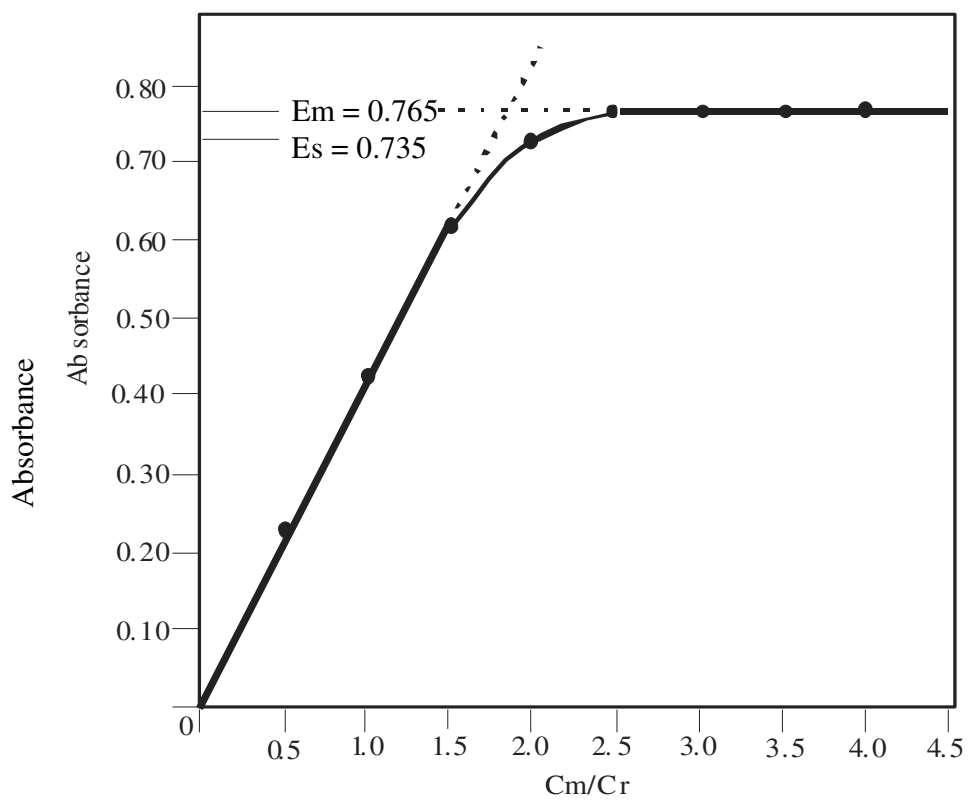

Graph - 3: Mole ratio method for $\mathrm{Cu}(\mathrm{II})-\mathrm{HMBO}$ complex

Yoe and Jone's mole ratio method for determination of M:L ratio $0.005 \mathrm{M} \mathrm{Cu}(\mathrm{II}), 0.005 \mathrm{M}$ HMBO; $\mathrm{pH}=5.0 ; \lambda=400 \mathrm{~nm}$

Determination of copper in brass

Exactly $0.5041 \mathrm{gm}$ of brass was taken dissolved in nitric acid $(1: 1)$. The excess nitric acid was boiled off and the solution was dilute to $100 \mathrm{ml}$ with distilled water. The aliquot $10 \mathrm{ml}$ was taken and $\mathrm{Cu}$ (II) was determined gravimetrically at pH 5.0 as described previously. Zn(II) and other trace metals did not interfere at this $\mathrm{pH}$. The experiment was repeated three times. $\mathrm{Cu}$ (found): $69.23 \%, \mathrm{Cu}$ (reported): $70.69 \%$

The same reagent has been taken for the determination of the other transition metal ions.

\section{Acknowledgement}

We are thankful to Prof. Dr. K. R. Desai, Head, Department of Chemistry, Veer Narmad South Gujarat University, Surat for providing the necessary facilities for the research work.

\section{References}

1 Desai K K and Naik H B, Indian J Chem, 1986, 25A, 297.

2 Desai B D and Desai K K, Asian J Chem, 2001, 13, 366.

3 Kahar P A and Desai K K, Asian J Chem, 1998, 10, 910.

4 Desai M J and Desai K K, Asian J Chem, 1999, 77, 1313.

5 Desai J J, Desai P G and Mehta A G, Asian J Chem, 1999, 77, 519.

6 Job P, Anal Chem, 1932, 115, 332.

$7 \quad$ Yoe J H and Jones A L, Ind Eng Chem, Anal Ed, 1944, 76, 777. 


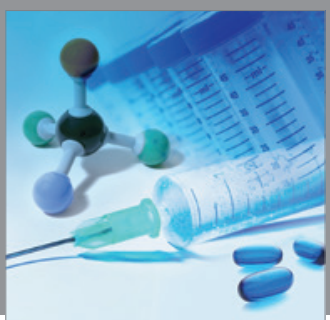

International Journal of

Medicinal Chemistry

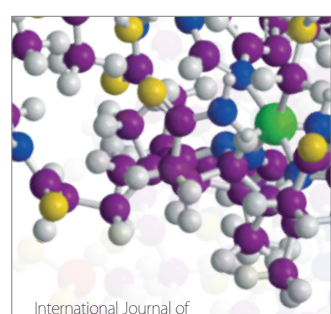

Carbohydrate Chemistry

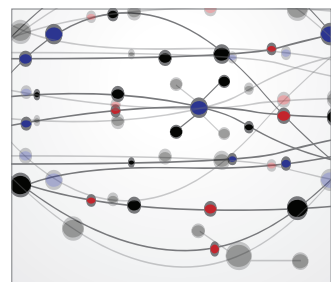

The Scientific World Journal
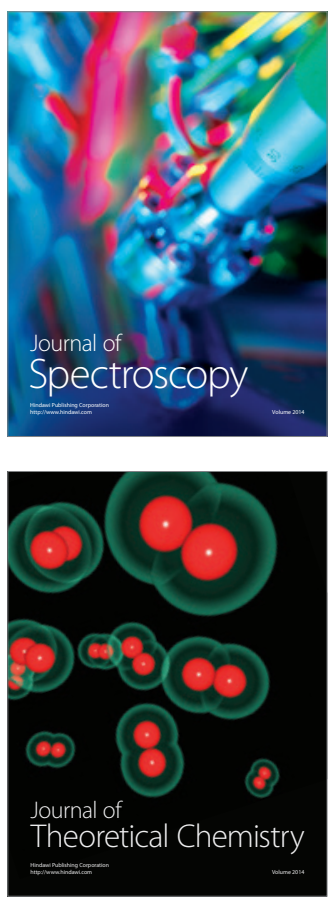
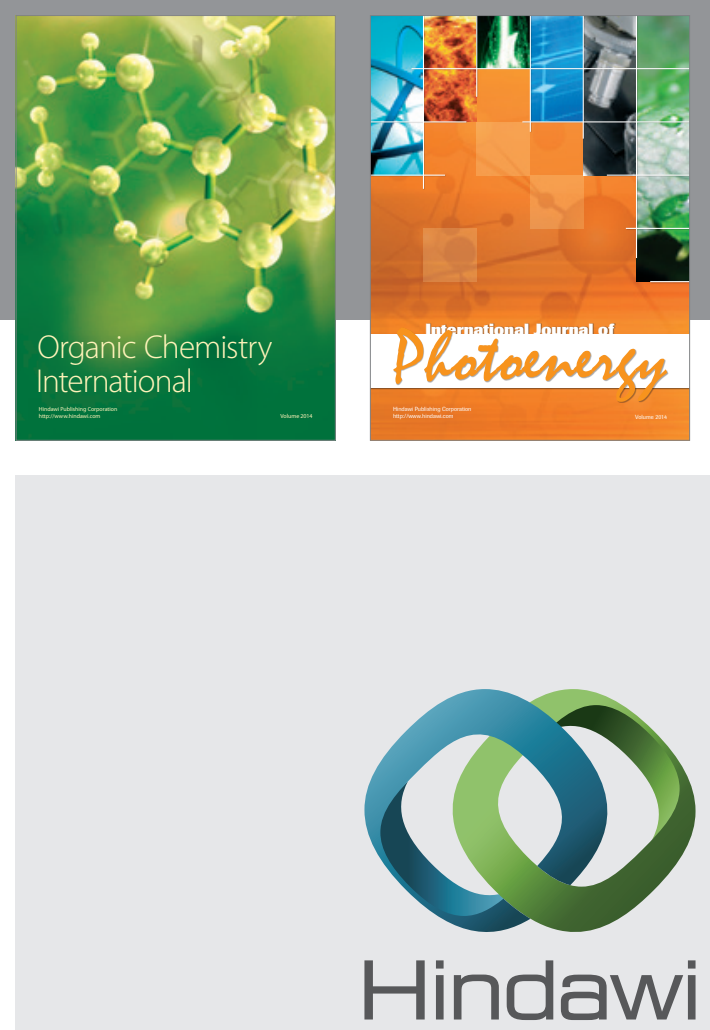

Submit your manuscripts at

http://www.hindawi.com
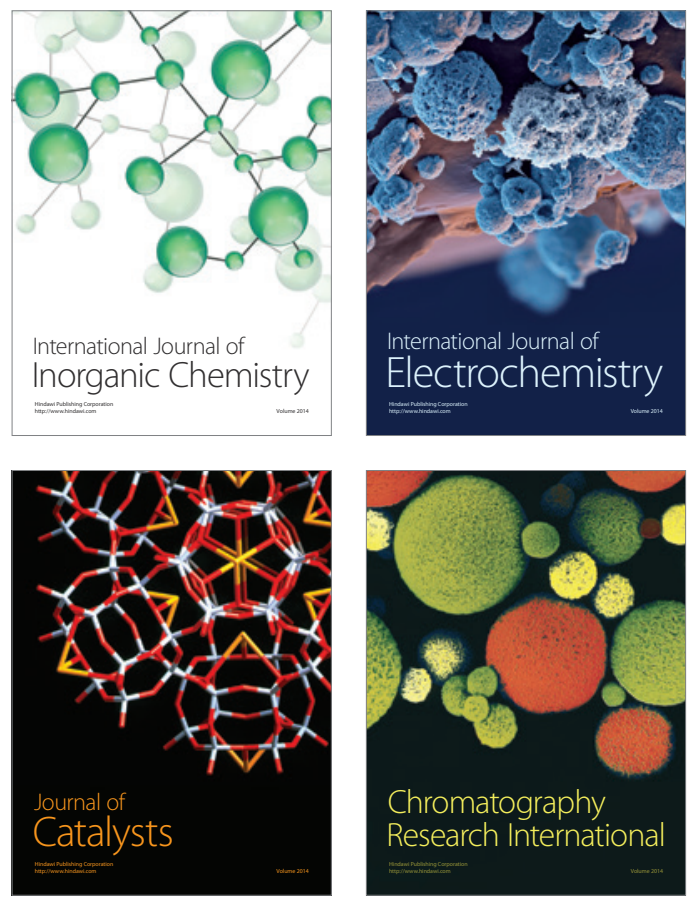
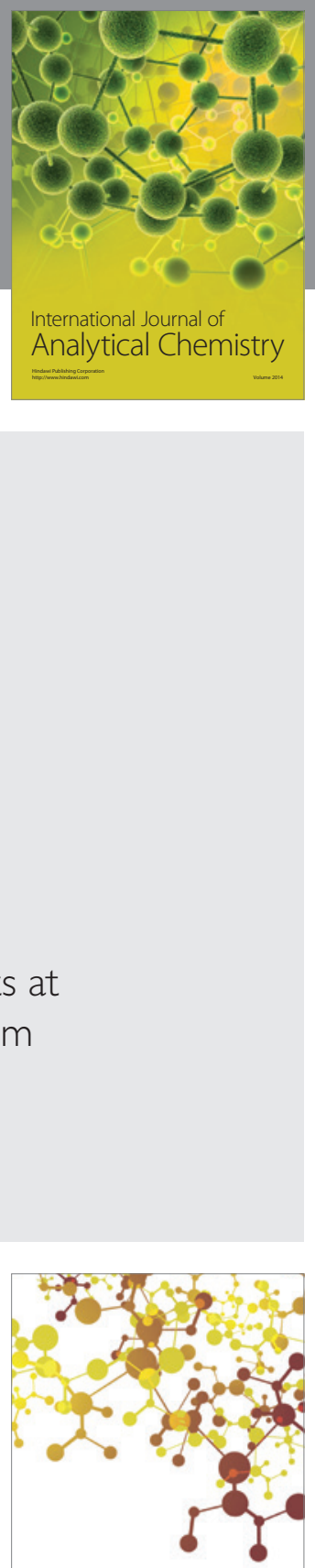

Journal of

Applied Chemistry
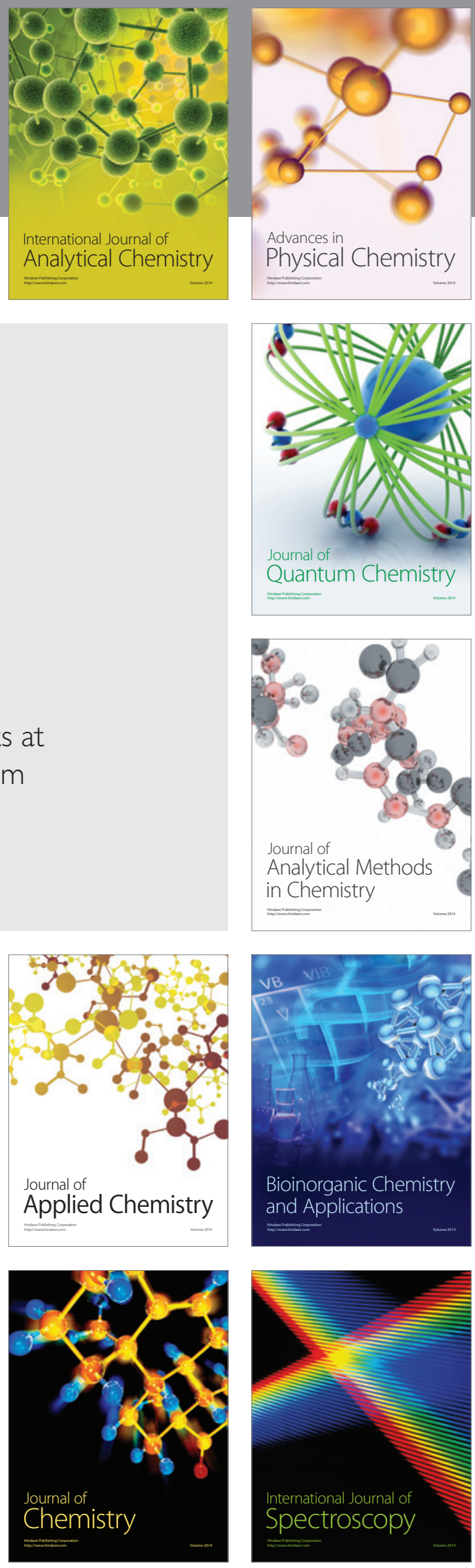